\title{
Governance for Management Consultants
}

\author{
Richard W. Leblanc
}

\section{Introduction}

It has always struck me how few qualified governance consultants there are. Although I have been a Certified Management Consultant (CMC) for the last twenty years, I normally do not consult to management. I consult to boards of directors, who oversee management.

The purpose of this article is to introduce management consultants to the governance field, in either (i) consulting to a board of directors, whereby governance consulting may be an addition revenue stream for CMCs, or (ii) sitting on a board of directors.

\section{Excuses for Poor Governance}

There is not an excuse I have not encountered over the years by boards (and directors themselves) and management teams not wishing to be properly governed.

Some of the most common excuses include the following:

- "It doesn't apply to our sector or company.";

- "It costs too much.";

- "It is too difficult to implement.";

- "We have never done it this way.";

- "Our board is perfectly fine.";

- "Regulators lack jurisdiction.";

- "Activists are short term.";

- "It is the law of unintended consequences.";

- "It is one-sized fits all approach."; and

- "Governance is only for the big players."

These excuses are defense mechanisms to preserve the status quo. If or when a board engages in these excuses and refuses to upgrade its governance to reflect current regulation and best practices, it does so with great risk. 
Enron (2001), the Global Financial Crisis (2008), and now COVID-19 (2019) have all been critical moments in corporate governance where regulators enact laws that saddles boards of directors with greater obligations.

\section{There Are No Bad Companies, Only Bad Boards}

Why is there a greater focus by regulators and investors on governance over the last twenty-five years?

If a company fails, it is the failure of the board of directors. It is not possible to have an effective board and an ineffective management team and company. A board should always be looking upward and outward, as well as inward and downward. Management may be in denial to the changes around them, or lack of performance, but a board of directors should never be in denial.

"There are no bad companies, only bad boards. Look to the board, not the company." - Richard Leblanc

The reason regulators and investors target boards in regulation and reform efforts is because management is accountable to a board, so the power rests with the board of directors in any organization. If management, who has the greatest effect on performance, needs to change but change does not occur, a complacent board is the reason. Regulation and activist investors would not be needed if boards were doing their job. This brings us to the responsibilities of boards of directors. What are the obligations of boards of directors?

\section{Responsibilities of Boards of Directors}

Every organization, regardless of its form (e.g., for-profit, not-for-profit, listed or stateowned, in no order) has a board of directors. There are important roles and responsibilities for any board, as follows:

\section{Hire, Fire and Pay the CEO}

First, the most important role of a board of directors is to hire, compensate, and, inevitably, fire, or succeed the incumbent CEO. Surveys suggest that this role is often near the poorest performed by boards and is the responsibility in which boards are often least confident. Why is this the case? Because the board does not have a sense of self and is unduly influenced by the incumbent CEO, who, understandably, does not wish to cooperate with succeeding themself. However, CEO succession is the board's responsibility, not the incumbent CEO's.

The most common regret directors have, expressed in interviews that I have conducted is "not firing the CEO sooner". Meeting after meeting, directors get lulled into excuses of under-performing CEOs, and go along. Replacing an under-performing CEO (and 50\% 
of all CEOs must be below average) takes time, experience, and courage, and is why activist investors are often needed to prompt and lead a complacent board to replace an under-performing CEO. Many boards, who may have hired the CEO to begin with (and thus are conflicted) or have been invited to the board by the CEO (and are even more conflicted), are not objective and do not see performance from an investor mindset. Such directors do not know what to do, like a fork trying to hold water, or refuse to act until it is too late.

\section{Review, Approve and Monitor the Execution of the Strategic Plan}

The second most important role of a board is to approve and monitor the achievement of the strategic plan of the company. The strategy should be comprehensive and include key performance indicators to measure the achievement of strategic directions (or pillars or value drivers, or the equivalent title) approved by the board. Strategy also includes values, purpose, vision, mission that should also be integrated and approved by the board.

The business model, value drivers, key performance indicators and risks of the organization should also be reviewed and approved by the board, as part of a strategic plan. A board should not approve any strategic plan unless all the foregoing elements are present. Many boards approve a strategic plan that is not measurable, including the non-financial elements, such as customer satisfaction, employee engagement, technology application, community impact and environmental sustainability. There is frequently a power point deck with aspirational, non-measurable outcomes, prepared by management, to placate a complacent board.

The non-financial, leading indicators comprise most of the value of a company now and should therefore feature prominently in any business model (Every company has a business model, even not for profit organizations and state-owned enterprises.). By the time the non-financial value drivers become financial, it is too late, and the board is looking in a rear-view mirror. Non-financial drivers are where value is created and are frequently the least mature and least measured. Why? Because the board is weak and does not insist that these drivers be measured by management. Anything can be measured, and the adage "if it is not measured, it is not managed" applies.

If a board cannot (i) measure the achievement (or not) of the entire business model and strategic plan by management; (ii) hold management responsible for achieving the plan; and (iii) incentivize strategic execution through links to incentive compensation, the board is failing at its strategic - and pay-for-performance - role.

\section{Review, Approve and Monitor the Risks}

Third, boards should understand, identify and approve the material financial and nonfinancial risks of the company, in writing. The risks should be defined, qualitatively and quantitatively. The internal controls to mitigate each risk, and their interaction, should be reviewed by the board. And the board should have independent assurance that such controls are operational and effective. 
The only individuals who can provide independent assurance of internal controls are the internal audit, compliance and risk functions, who should report to the board and the relevant committee of the board overseeing each risk in first instance.

Many boards make the mistake of not taking steps to approve the controls and the independent assurance of the controls. Management dominates the discussion, and there is a nebulous, opaque discussion of risk. "Trust us" are the words most frequently used by management (who dislike controls) to satisfy a board. Meanwhile, acute risks, such as data integrity, reputation, health and safety, supply chain resiliency, and people risk go unchecked.

In every risk failure I have advised upon, it has been a board that did not ask for the right risk information and relied on management's oral assurance, rather than on what regulators are asking for - namely controls and assurance by the board. Duty of care, or acting as a reasonably prudent person would act under similar circumstances, means that as the risks change, the board needs to ensure that the controls and assurance change as well. Many boards fail to do this, and if the above rigor is not in place during a steady state, when the risks change by an exogenous event such as COVID-19, it is too late for a complacent board to act because it has relinquished oversight to management already.

\section{Set and Adhere to the Tone at the Top}

Fourth, and perhaps most importantly, tone at the top and throughout the organization is established by a board of directors. A board, through a board committee or directly, should oversee whistle-blowing complaints of potential wrongdoing, compliance with the code of conduct, and ethical business practices (including anti-money laundering, antibribery and proper procurement). Good boards also oversee conduct risk, and the incentive pay structure through the organization to promote ethical conduct.

A board should take swift action at any wrongdoing within the organization. Good tone is clear, immediate and consequential. A common regret that directors have told me is not speaking up when they had the chance, particularly when it comes to ethics. What a director sees, reads, and hears is what the director has accepted if the director does not speak up. Good boards have in camera meetings every meeting, with only independent directors in the room, to increase the ability of directors to speak candidly without management present.

\section{Have Effective Board Committees}

Lastly, a board must establish effective committees. Committees are where the work gets done, in reviewing and recommending actions and decisions to the board. Committees do not approve or decide but review and recommend.

One ineffective committee, with an ineffective committee chair, can compromise governance and therefore the company. Committee reporting to the board must be robust, evidence the due diligence of the committee, and not be oral in nature. 
We now turn to the role of CMCs in possibly consulting to boards of directors given their management consulting expertise.

\section{Consulting to Boards of Directors}

Consulting to a board of directors is different from consulting to management. The average size of a board is seven to eleven directors, and directors are all peers. So, the acquisition of, and delivering of advice to, a client is to a group of peers.

This brings up the point of who is the client of a governance consultant?

\section{Who is Your Client?}

For a governance consultant, it is important to establish who the client is at the beginning of any engagement. In my view, the client for a governance consultant should always be the governance committee (or the equivalent) of the board, or the board of directors itself.

There may be (and is often) a tendency for management to interfere in the choice and compensation of the governance consultant. Management is very sensitive with board consultants. If or when management interference happens, an experienced governance consultant should advise management that the client is not management, and management should stand down from interfering with the governance consultant's client relationship with the committee or board.

The governance consultant's client is also not the chair of the board, nor any individual director. If there the board is ineffective, the board chair is also ineffective. It is not possible to have an effective board chair and an ineffective board. Ineffective boards go hand in hand with ineffective chairs, so the consultant should not be beholden to the board chair as a client, because this may compromise the rendering of independent necessary advice. The consultant should be free to recommend courses of action with which the board chair may disagree, including coaching for the board chair, other remedies, and, if necessary, board chair removal.

Any board committee and the board should have, within their written terms of reference, the authority to retain any independent advisor the committee or the board deems appropriate, without the participation, interference or consent of management.

\section{What Makes for a Good (and Poor) Director?}

Not all directors are equally effective, and this includes on boards of large, complex public companies. (There is often the myth that larger companies have more effective boards. This is untrue.) In any given survey, including the ones I undertake, there is always: one third of directors who are outstanding and highly effective; one third of directors in the middle; and one third of directors who are under-performing and need 
development (or removal from the board). What are some of the qualities and criteria that define effective and ineffective directors?

\section{Independence of Mind}

Normally, director independence means independence from the company and management. Independent directors should be independent and seen to be independent from both. The only relationship an independent director should have with the company is the directorship itself. The only compensation (or any type of reward or perquisite) an independent director should receive should be for board- and committeerelated responsibilities only.

There are social and other relationships that may not be captured by formal independence requirements and may (and often do) undermine independence of a director. Once the independence of one director, and especially a board or committee chair, is undermined, the board now works for management, rather than the other way around. I have never seen a director move from independent to dependent, and then back to independent. The movement is from independent to dependent only. In addition, gifts, honoraria and other perquisites, such as an office and excessive tenure as a director (over nine or ten years) can also undermine effective and independent board service.

\section{Knowledge of the Business}

The most common complaint management has of their board is the lack of knowledge of the business. This is hardly surprising given the emphasis by regulators on independent directors. Aside from recruiting some independent directors with industry expertise, most independent directors on boards are not from the sector. This means that such directors must invest the time - significant time at the front end of their directorship - to understand the business of the company (any company, including not for profit organizations) and the industry in which it operates.

Many directors make the mistake of defaulting into their comfort zone, particularly industry, legal or accounting directors, rather than adding strategic value to the management team. Consultants, lawyers and accountants can be hired by a board or a management team. Good directors are now advising management with twenty- or thirtyyears experience in the industry that directors do not have. A director who asks compliance questions all the time, rather than strategic questions, is apparent to other directors and certainly to management.

This brings us to the next requirement to be effective as a director: Asking questions properly.

\section{Asking Effective Questions}

The job of directors is to ask good questions. The job of management is to respond to the questions that directors ask, candidly, openly and constructively.

Many chairs or directors will state that there are no stupid questions. I disagree. There are stupid questions, and there are also inappropriate questions. The time for dialogue 
in a board or committee meeting is not for education. If there is a question that is in the pre-reads, that is not a good question.

A good question is a strategic question. It forces management to think. A question has component parts. I look at the frequency of question, the duration of the question, the timing of the question, the words in the question, the body language of the director in asking the question, and the nature of the question itself. Asking good questions as a director can be learned, but not always.

\section{Maintaining an Oversight Role}

There is a tendency for newer, industry, or professional (law, accounting, consulting) directors to ask excessively detailed, operational or management questions, rather than oversight, governance and value-added strategic questions.

If or when a director engages in excessively micro-managing questions, that director should be promptly mentored by the board or governance committee chair, and corrected in their questions.

\section{Maintaining Competencies and Currency}

Boards should utilize a competency or skills matrix to guide the desired skills needed in successor directors, and development and strengthening of key competencies for incumbent directors. Directors cannot be good at every skill, nor are they expected to be. But they should be expected to keep current on those competencies and skills important to the strategy and business of the company.

\section{Behaving Properly}

Behaviour matters and can be recruited for. Leadership, communication skills, impact, influence and teamwork are behaviours of directors that may be developed or mentored. Good boards have behavioural matrixes that are used to guide director recruitment and development for new and incumbent directors respectively.

Boards should conduct written peer assessments annually to assess the above behaviours in directors. A director with a behaviour that is problematic can cause a rift and dysfunction in the board, and between the board and management. A dysfunctional behaviour should be coached as I will address shortly.

\section{Technological Adeptness}

Directors should understand technology, including its application to the industry on the board on which they serve. This includes data integrity, artificial intelligence, blockchain, virtual and augmented reality, and internet of things, as applied to the company and its industry.

Directors should also, given virtual meetings, be proficient in conducting and participating effectively in virtual meetings, including adequate lighting, high speed and 
reliable internet, work from home cyber protections, and a professional camera and microphone.

\section{Solidarity and Resiliency}

The final criteria for being a good director is solidarity and resiliency.

Solidarity means supporting a board decision fully once it is taken, even if a director may not have agreed with the decision. Resiliency means re-establishing health boardroom dynamics after a contentious issue or vote, and not holding grudges or pouting in any way. One director not exhibiting solidarity or resiliency can disrupt a health boardroom dynamic.

\section{Can a Director Be Coached?}

I have been asked to coach directors on behavioural issues. I have learned that not all directors are coachable. To be coachable as a director requires two contributors: (i) selfawareness, and (ii) an intention to improve in a way that is sustainable. Many directors have (i) but not (ii). There is what I call, reversion to past behaviours.

A director in need of coaching, as judged by the governance committee or the board itself, should be offered coaching and development, either by another director or an external consultant. If, after a reasonable period, the dysfunctional behaviour or other form or under-performance continues, i.e., the director is not redeemable, that director should be asked by the board to stand down. Many boards make the mistake of allowing an under-performing director to continue the board, thinking that the board will wait out the director's tenure. When this happens, talent flight may occur, or it becomes more difficult to recruit top tier directors and even a next CEO.

\section{Questions to Ask Before Joining a Board}

We turn now to questions that prospective directors should ask when interest in the director has been expressed by the board, or the nominating committee of the board, or shareholders or a body or entity who has authority to recommend a director to a board. Here are the following questions that prospective directors should be asking.

\section{Time Commitment Expected}

What type of time commitment is expected? The average directorship is more than 250 hours, so the time commitment is not insignificant. A practicing executive should receive permission from the home company CEO (or board if the executive is the CEO) before agreeing to join an external board.

For a practicing management consultant, the opportunity cost of the directorship should be factored into any decision calculus, as well as conflicts of interest in consulting engagements by virtue of board service. 


\section{Ethics and Compliance Checks}

A prospective director should conduct a thorough due diligence check on each director and officer of the company, for misconduct, criminal behaviour, litigation, tax evasion, and reputational contagion. Directors are peers and often will have joint and several liability, so wrongdoing by one director may affect assets and reputations of another.

A non-disclosure agreement should be signed, and any outstanding litigation, audit concerns, regulatory investigations or sanctions should be requested by the prospective director.

Lastly, the director should conduct due diligence on the company itself, for wrongdoing, reputation, financial mismanagement, and regulatory or other stakeholder concerns.

\section{Some of the Best Decisions Are "No"}

If there are any ethical red flags that surface during the above due diligence search, the prospective director should refuse the directorship. The person to preserve the reputation and assets of a director is the director by what is done, and as importantly what is not done. Some of the best decisions, as management consultants know, is to refuse a problematic client. It is the same with board positions.

Liability begins as soon as one steps onto a board. And if a mistake is made, and a director joins a board and then stands down, regulators have long arms and the liability continues for actions the director took, or did not take, whilst on the board.

Most ethical concerns were or should have been known prior to accepting the directorship, so diligence is intelligence gathering. Directorships are accepted without rose-colored classes, but with eyes wide open.

\section{Insurance and Indemnification}

A prospective director should assume that the director can and will be sued by plaintiff's counsel during the directorship. Review the director and officer insurance policy (the actual copy, not management's summary of the policy), and ask about the adequacy of coverage, indemnification, and the advancement of legal fees in the event of litigation. Assume a worst-case scenario and receive comfort about the adequacy and advancement of coverage and fees.

\section{Reporting and Disclosure}

Ask to review all financial, tax, and non-financial reporting and compliance with regulations. Liability can attach for unpaid employee wages, tax remittances, of other offences. See the audited financial statements, external counsel reports and (if the company is public) securities filings. If the company is not-for-profit, review the Internal Revenue Service's Form 990 for key reporting and disclosure issues.

\section{Compensation}


Lastly, ask about compensation for director service, including structure and quantum. There are a variety of practices here, including cash, equity, options, and based on board, committee, chair, committee chair and director retainers and meeting fees (in person, phone and now virtual).

\section{Conclusion}

Consulting to a board, or sitting on a board, by CMCs can offer beneficial dividends. I hope this article has been useful to CMCs and all management consultants.

I am sincerely grateful for receiving the honor of Academic Fellow from the International Council for Management Consultants. 


\section{References}

Leblanc, Richard, ed., The Handbook of Board Governance: A Comprehensive Guide for Public, Private, and Not for Profit Board Members, 2nd ed., San Francisco: Wiley (2020).

Leblanc, Richard, ed., The Handbook of Board Governance: A Comprehensive Guide for Public, Private, and Not for Profit Board Members, San Francisco: Wiley (2016).

Leblanc, Richard, "Forty Proposals to Strengthen: the Public Company Board of Director's Role in Value Creation; Management Accountability to the Board; and Board Accountability to Shareholders," International Journal of Disclosure and Governance (2013) 1-16. 